\title{
TINDAK PIDANA BULL YING YANG DILAKUKAN ANAK DIBAWAH UMUR MELALUI KEADILAN RESTORATIVE JUSTICE
}

\author{
I Made Rai Dwi Surya Atmaja, Anak Agung Sagung Laksmi Dewi, Ni Made Sukaryadi Karma \\ Fakultas Hukum Universitas Warmadewa, Denpasar-Bali, Indonesia \\ Suryaatmaja712@gmail.com Laksmidewii29@gmail.com Sukariati64@gmail.com
}

\begin{abstract}
Abstrak
Tindakan Bullying adalah penggertakan yang kerap memicu pada sebuah perbuatan buruk yang mengandung kejahatan, tetapi luput dari perhatian. Berdasarkan penelitian ini penulis mengangkat rumusan masalah: 1 . Bagaimanakah perlindungan hukum terhadap anak korban tindak pidana bullying?, 2. Bagaimanakah penyelesaian tindak pidana bullying melalui keadilan restorative justice?. Tipe Penelitian ini adalah hukum normatif. Pendekatan masalah penelitian ini terdapat pendekatan secara perundang-undangan, pendekatan konseptual, dan pendekatan kasus. Metode penelitian yang digunakan yaitu, penelitian hukum normatif, dengan melakukan pengkajian berdasarkan bahan hukum dari buku hukum dan merupakan dari suatu proses untuk menemukan aturan hukum. Sedangkan untuk pendekatan masalah didalam penelitian ini yaitu Pendekatan secara Perundang-undangan (Statute Approach) dan Pendekatan Konseptual (Conceptual Approach) serta Pendekatan Kasus (Case Approach). Hasil penelitian menunjukkan bentuk perlindungan hukum terhadap anak korban tindak pidana bullying diatur didalam beberapa Peraturan Perundang-undangan yaitu, pada Kitab Undang-Undang Hukum Pidana, Undang- Undang Nomor 35 Tahun 2014 tentang Perubahan Atas UndangUndang No. 23 Tahun 2002 tentang Perlindungan Anak, Undang-Undang Nomor 19 Tahun 2016 tentang Perubahan Atas Undang-Undang Nomor 11 Tahun 2008 tentang Informasi dan Transaksi Elektronik. Upaya penyelesaian tindak pidana bullying melalui restorative justice menggunakan Non litigasi atau penyelesaian sengketa di luar pengadilan. Pokok penyelesaian perkara pada keadilan restoratif didasarkan dari para pihak untuk mengungkapkan pendapat untuk menghasilkan kesepakatan. Upaya penanggulangan kejahatan terdapat dua macam yaitu upaya penal dan non penal. Diharapkan pemerintah, instansi yang bergerak di bidang penegak hukum dan di bidang pendidikan serta masyarakat melakukan upaya yang tegas terhadap tindak pidana bullying.
\end{abstract}

Kata kunci: Bullying; Keadilan restoratif; Anak

\begin{abstract}
Bullying is bullying that often leads to bad deeds that contain crime, but goes unnoticed. Based on this research, the authors raise the formulation of the problem: 1. How is legal protection for child victims of bullying?, 2. How is the settlement of bullying crime through restorative justice? This type of research is normative law. The approach to this research problem is a statutory approach, a conceptual approach, and a case approach. The research method used is normative legal research, by conducting studies based on legal materials from legal books and is a process of finding legal rules. As for the problem approach in this study, namely the statutory approach (statute approach) and the conceptual approach (conceptual approach) and the case approach (case approach). The results show that the form of legal protection for child victims of criminal acts of bullying is regulated in several laws and regulations, namely, the Criminal Code, Law Number 35 of 2014 concerning Amendments to Law No. 23 of 2002 concerning Child Protection, Law Number 19 of 2016 concerning Amendments to Law Number 11 of 2008 concerning Electronic Information and Transactions. Efforts to resolve criminal acts of bullying through restorative justice using non litigation or settlement of disputes outside the court. The point of settlement of cases on restorative justice is based on the parties to express their opinions to produce an agreement. There are two kinds of crime prevention efforts, namely penal and non-penal efforts. It is hoped that the government, agencies engaged in law enforcement and education as well as the public will make firm efforts against the crime of bullying.
\end{abstract}

Keywords: Bullying; Restorative justice; Child 


\section{PENDAHULUAN}

Negara Indonesia diakui sebagai negara hukum, ciri khasnya yaitu mengakui terdapat suatu pengakuan pada HAM (Dahlan Talib, Jazim Hamidi, 2010). Indonesia diakui memiliki peraturan sistem pemidanaan yang sangat terkait dengan sanksi pidana. Hukum pidana mengandung tanggungan yang lebih tegas daripada yang lainnya (Sambas, 2010). Pelaksanakan penggunaan sistem peradilan pidana anak yaitu Keadilan restoratif (Restorative Justice). Menurut Undang-Undang Nomor 11 Tahun 2012 tentang Sistem Peradilan Pidana Anak. Pasal 1 Ayat 8 berbunyi bahwa, "Keadilan restoratif adalah penyelesaian perkara tindak pidana dengan melibatkan pelaku,korban, keluarga pelaku/korban dan pihak lain yang terkait untuk bersama-sama mencari penyelesaian yang adil dengan menekankan pemulihan kembali pada keadaan semula dan bukan pembalasan".

Perilaku Bullying adalah penggertakan yang sering memicu terjadinya perbuatan buruk yang mengandung tindakan kejahatan (Suryani, 2016). Bullying merupakan sebagai kekerasan fisik, verbal dan psikologis yang dirasakan dalam jangka waktu lama yang dilakukan oleh seseorang atau banyak orang kepada seseorang yang tidak bisa bertahan diri dari keadaan, adanya keinginan menakuti, melukai, atau membuat orang menjadi tidak bisa bertahan hingga tidak bernyawa. Suatu ejekan, cemoohan, olok-olok dianggap biasa saja, namun kenyataan yang terjadi secara perlahan dapat menghancurkan seorang anak.Perbuatan negatif tersebut ialah sebagai wujud dari bullying, Perilaku yang sudah lama terjadi dan mengancam anak saat disekolah, rumah, serta lingkungan.Kualitas pendidikan di Indonesia saat ini sangat memprihatinkan, terbukti dengan terjadinya peristiwa bullying pada pelajar saat ini, tetapi tidak mendapatkan perhatian.

Terdapat data pada tahun 2016-2020 yang dirilis oleh Kementerian Pemberdayaan Perempuan dan Perlindungan Anak (Kemen-PPPA), adanya sejumlah 40\% siswa rentangan usia 13-15 tahun dilaporkan pernah mengalami kekerasan fisik oleh teman sebaya dan sejumlah $75 \%$ siswa berbicara pernah melakukan kekerasan di sekolah. Tidak habis pikir sejumlah $50 \%$ anak dilaporkan mengalami perundungan atau bullying di sekolah.

Setiap semua orang termasuk anak dibawah umur yang termasuk tindak pidana wajib melakukan proses hokum (Amrunsyah, 2017), baik itu secara pemeriksaan hingga mencapai putusan pengadilan, tetapi untuk anak-anak di bawah umur mendapatkan perlakuan khusus sebagai bentuk perlindungan. Penanggulangan berbagai perbuatan menyimpang anak tidak boleh melupakan kedudukannya, walau anak- anak dibawah umur melakukan perbuatan sesuai keinginannya tetapi lingkungan sekitar anak mempunyai pengaruh yang besar akan dapat mempengaruhi anak dalam mengambil sikap. Pada dasarnya, anak-anak di bawah umur tidak dapat menghadapi berbagai segi macam tindakan yang sangat berdapak negatif bagi dirinya sendiri dalam melanjutkan hidup.

Perlu adanya upaya perlindungan anak yang dilakukan secepat mungkin, dari saat janin dalam kandungan sampai umur 18 (delapan belas) tahun karena banyaknya anak dibawah umur yang menjadi korban bullying maupun pelaku bullying kurang mendapatkan perhatian khusus.

Terkait penelitian terdahulu oleh (Raodathul Jannah, Tonny Rompis, 2018) dan (Chrysan et al., 2020) menyatakan bahwa tindakan bullying yang berdampak negatif tersebut ialah suatu tindak pidana dan diperlukan penerapan sanksi pada pelaku bullying secara tegas. Tidak hanya menimbulkan efek jera namun sanksi tersebut diupayakan agar dapat memperbaiki perilaku, mengingat seorang anak adalah generasi penerus bangsa sehingga penerapan sanksi tindakan pada anak yang diatur dalam Pasal 82 ayat (1) huruf e Undang-Undang Nomor 11 Tahun 2012 tentang Sistem Peradilan Pidana Anak yaitu kewajiban mengikuti pendidikan formal dan/atau pelatihan yang diadakan oleh pemerintah atau badan swasta. Adapun tujuan penelitian ini yaitu mengetahui perlindungan hukum terhadap anak korban tindak pidana bullying, dan mengetahui cara penyelesaian tindak pidana bullying melalui keadilan restorative justice.

\section{METODE PENELITIAN}

Metode penelitian yang digunakan yaitu, penelitian hukum normatif, dengan melakukan pengkajian berdasarkan bahan hukum dari buku hukum dan merupakan dari suatu proses untuk menemukan aturan hukum. Sedangkan untuk pendekatan masalah didalam penelitian ini yaitu Pendekatan secara Perundang-undangan (Statute Approach) dan Pendekatan Konseptual (Conceptual Approach) serta Pendekatan Kasus (Case Approach). Pendekatan Perundang-undangan (Statute Approach) adalah dilaksanakan dengan memperhatikan semua peraturan yang berkaitan dengan masalah yang sedang 
terjadi saat ini. Sedangkan Pendekatan Konseptual (Conceptual Approach) adalah pendekatan yang melihat dari sudut pandang yang ada di dalam ilmu hukum, serta Pendekatan Kasus (Case Approach) adalah pendekatan yang membangun pendapat-pendapat hukum dalam sudut kasus nyata yang sedang terjadi di lingkungan saat ini, pastinya kasus ini saling berkaitan dengan peristiwa hukum di lingkungan. Pendekatan ini bermaksud mencari apa yang sebenarnya terjadi baik itu kebenarannya dan mencari solusi terbaik dari perilaku yang sudah dibuat.

\section{HASIL DAN PEMBAHASAN}

\section{Perlindungan Hukum terhadap Anak Korban Tindak Bullying}

Perlindungan hukum merupakan perbuatan atau upaya dalam melindungi seluruh masyarakat dari perilaku seseorang yang tidak mempunyai etika, dalam menciptakan ketertiban dan ketentraman yang akan memberikan kenyamanan sebagai manusia menjalani hidup (Setiono, 2004). Perlindungan hukum yaitu perlindungan yang harus didapatkan seluruh manusia, dan harus mendapatkan hak-haknya sebagai manusia yang telah berdasarkan hukum dari larangan atau sebagai bersatunya peraturan yang dapat melindungi semua hal.

Bullying ialah sebuah situasi terjadinya penyalahgunaan kekuasaan yang dilakukan oleh seseorang/sekelompok.Bullying juga merupakan hasrat untuk menyakiti, dari tindakan yang menyebabkan seseorang menderita, yang dilakukan secara langsung dan berulang dengan perasan senang.Bullying merupakan penggertakan yang sering terjadi untuk memicu perbuatan buruk yang mengandung tindakan kejahatan.

Tindak pidana Bullying bisa diinterpretasikan terhadap berbagai peraturan yang telah ada dalam hukum pidana di Indonesia, yang ada di dalam Kitab Undang-Undang Hukum Pidana (KUHP), dalam mengatur tindak pidana bullying adalah yang tercantum dalam Bab XVI mengenai Penghinaan, khususnya Pasal 310 Ayat (1) dan (2). Terdapat juga perlindungan hukum terhadap anak korban tindak bullying menurut Undang-Undang Nomor 35 Tahun 2014 tentang Perubahan Atas UndangUndang Nomor 23 Tahun 2002 tentang Perlindungan Anak. Memberikan hukuman pidana bagi pelaku kekerasan terhadap anak terdapat pada Pasal 80 Ayat (1), (2), (3), dan (4). Perlindungan hukum terhadap anak korban bullying menurut Undang-Undang Nomor 19 Tahun 2016 Tentang Perubahan Atas Undang-Undang Nomor 11 Tahun 2008 Tentang Informasi Dan Transaksi Elektronik.Telah mengatur tentang tindakan kekerasan melalui media informasi dan media sosial, terutama untuk pelaku cyberbullying.Undang-undang ini menerapkan larangan dan sanksi pidana yang terdapat khususnya Pasal 27 ayat (1), (3), dan (4).

\section{Penyelesaian Tindak Pidana Bullying melalui Restorative Justice}

Restorative Justice Adalah terminology asing baru dikenal dengan istilah Keadilan Restoratif. Keadilan restoratif yaitu cara dalam melibatkan semuanya yang terdiri dari korban, pelaku kejahatan dan masyarakat sehingga menghasilkan keadilan semuanya serta menciptakan suasana semula sebelum terjadi permasalahan kejahatan.

Secara umum untuk penyelesaian tindak pidana atau sengketa dapat menggunakan dua jalur yaitu jalur Litigasi dan Nonlitigasi. Penyelesaian sengketa melalui pengadilan atau Litigasi ialah proses penyelesaian di pengadilan yang memerluka keterlibatan semua orang yang bersengketa saling mengeluarkan pendapat agar tetap memegang hak-haknya pada saat di muka pengadilan (Amriani, 2012). Sedangkan penyelesaian sengketa di luar pengadilan atau Non litigasi ialah penyelesaian sengketa dari berbedanya pendapat yang sudah melakukan jalur yang ditetapkan disepakati semua pihak, yang dilakukan melalui mediasi serta penilaian dari ahli. Pada penyelesaian tindak pidana bullying dengan restorative justice menggunakan jalur penyelesaian sengketa di luar pengadilan (Non litigasi). Proses penyelesaian tindak pidana yang berdasarkan keadilan restoratif melalui mediasi dari semua pihak yang terlibat untuk setuju mencari kesepakatan kedamaian.

Menyelesaikan tindak pidana melalui keadilan restoratif ini memfokuskan adanya keterlibatan langsung dari semua pihak baik itu dari pelaku, korban dan masyarakat dalam proses menyelesaikan perkara. Keadilan restoratif pastinya memperhatikan nilai-nilai yang bersifat kedamaian, keharmonisan, ketentraman dan kekeluargaan, tidak berfokus pada pemenjaraan seseorang. Prinsip keadilan restoratif dapat diartikan dengan sederhana bahwa menyelesaikan tindak pidana yang memperhatikan keadilan dari semua para pihak yang terlibat. 
Agar terciptanya kedamaian semua para pihak yang terlibat dalam sengketa dapat bertujuan agar mewujudkan sengketa tersebut menjadi bisa dinetralisir agar pelaku dan korban bisa kembali mempunyai ikatan yang seperti keadaan terdahulu agar bisa dapat menciptakan suasana perdamaian tersebut.

Dalam Upaya penanggulangan tindak pidana dikenal dengan istilah kebijakan kriminal seperti: penal policy, criminal policy, atau strafrechtspolitiek merupakan suatu usaha untuk menanggulangi kejahatan melalui penegakan hukum pidana, rasional yaitu memenuhi rasa keadilan dan daya guna. Untuk menghadapi kejahatan pada semua yang ada dari pelaku kejahatan dapat memberikan hukum pidana maupun non pidana sehingga dapat teratasi dengan yang lainnya. Jika terjadi kejahatan upaya penanggulannya dilaksanakan hukum pidana yaitu pemilihan hasil perundang-undangan pidana sesuai dengan suasana yang ada pada waktu selanjutnya

Upaya untuk menghindari kejahatan yang terjadi ialah memberikan para pelaku kejahatan seperti sarana pidana (penal) ataupun tidak hukum pidana (non-penal), sehingga dapat berkaitan dengan yang lainnya. Jadi dapat disimpulkan bahwa semua masyarakat memerlukan ketentraman sebagai wujud perlindungan. Adanya Upaya-upaya yang digunakan dalam rangka penanggulangan kejahatan dapat dibedakan menjadi dua macam yaitu sebagai berikut:

1. Upaya penal, ialah suatu upaya untuk tidak terjadi kejahatan dengan cara pikiran atau konsepsi. Penanggulangan dengan upaya represif dapat diartikan memberikan hukuman tegas bagi pelaku kejahatan atas melakukan perbuatan yang tidak baik yang pastinya sudah melanggar hukum dan sangat memberikan dampak negatif pada masyarakat lainnya, agar pelaku tidak mengulangi perilakunya kepada orang lain, bahwa diingatkan ada hukuman yang harus ditaati serta di pertanggung jawabkan.

2. Upaya non penal (preventif), dasar dari non-penal policy makin menekankan dengan tindakan preventif, bertujuan untuk mencegah jauh sebelum terjadinya kejahatan. Dengan demikian, upaya preventifmerupakanusaha yang baik untuk menanggulangi kejahatan, jadi perlu adanya perintah tegas dari semua aparat penegak hukum yang bertugas untuk memberikan keamanan agar menjauhkan dari terciptanya kejahatan.

\section{SIMPULAN DAN SARAN}

\section{Simpulan}

Berdasarkan pembahasan diatas, maka dapat ditarik kesimpulan bahwa perlindungan hukum terhadap anak korban tindak pidana bullying, diatur didalam beberapa Peraturan Perundang undangan yaitu, pada Kitab Undang-Undang Hukum Pidana, Undang-Undang Nomor 35 Tahun 2014 Tentang Perubahan Atas Undang-Undang No. 23 Tahun 2002 Tentang Perlindungan Anak, UndangUndang Nomor 19 Tahun 2016 Tentang Perubahan Atas Undang-Undang Nomor 11 Tahun 2008 Tentang Informasi dan Transaksi Elektronik.

Upaya penyelesaian tindak pidana bullying melalui restorative justice menggunakan jalur menyelesaikan sengketa di luar pengadilan atau non litigasi. Pokok untuk menyelesaikan permasalahan melalui keadilan restoratif ialah semua pihak terlibat melewati mediasi agar semua pihak yang terlibat mendapatkan hasil kesepakatan bersama, menyelesaikan permasalahan pidana melalui keadilan restoratif, lebih berpusat pada ketentraman, kesejahteraan, keharmonisan dan kekeluargaan, tidak memusatkan pada pemenjaraan seseorang. Prinsip keadilan restoratif dapat diartikan dengan sederhana bahwa menyelesaikan tindak pidana yang memperhatikan keadilan dari semua para pihak yang terlibat untuk mencapai kesepakatan perdamaian bersama. Adapun upaya penanggulangan kejahatan dibedakan menjadi 2 macam yaitu Upaya penal (represif) ialah upaya menanggulangi kejahatan melakukan hukum pidana di dalamnya, dan Upaya non penal (preventif) ialah kebijakan penanggulangan kejahatan yang melaksanakan proses berpendapat bersama untuk menciptakan suasana semula sebelum adanya kejahatan.

\section{Saran}

Berdasarkan pembahasan serta kesimpulan penelitian ini, dapat dikemukakan beberapa saran, yaitu : Pemerintah maupun masyarakat perlu melakukan upaya-upaya yang bertujuan meminimalisir tindak pidana bullying yang berujung penganiayaan berat yang mengakibatkan korban hingga meninggal dunia. 
Instansi-instansi yang bertugas dalam bidang penegak hukum untuk memutuskan perintah tegas dan nyata dalam menindaklanjuti pada permasalahan tindak pidana bullying agar semua orang tidak mencontohkan perilaku tersebut.

Instansi-instansi yang bertugas dalam bidang pendidikan seperti Guru, Kepala Sekolah, Dosen perlu memberikan perlindungan pengawasan terhadap anak didiknya, agar setiap perilaku menyimpang dari anak didik dapat diketahui.

\section{DAFTAR PUSTAKA}

Amriani, N. (2012). Mediasi Alternatif Penyelesaian Sengketa Perdata di Pengadilan. Grafindo Persada.

Amrunsyah. (2017). Tindak Pidana Perlindungan Anak (Perspektif Hukum Tentang Undang-Undang Perlindungan Anak). Jurnal Hukum Islam Dan Perundang-Undangan, 4(1).

Chrysan, E. M., Rohi, Y. M., Saputri, D., \& Apituley, F. (2020). Penerapan Sanksi Tindakan Anak yang Melakukan Bullying dalam Perspektif Sistem Peradilan Pidana Anak. Jurnal Hukum Magnum Opus, 3(4), 162-172.

Dahlan Talib, Jazim Hamidi, N. H. (2010). Teori dan Hukum Konstitusi. Rajawali Press.

Raodathul Jannah, Tonny Rompis, L. S. (2018). Pertanggungjawaban Pidana oleh Anak Pelaku Bullying. Lex Crimen, 7(3), 1-15.

Sambas, N. (2010). Pembaharuan Sistem Pembinaan Anak di Indonesia. Graha Ilmu.

Setiono. (2004). Rule of Law.

Suryani. (2016). Stop Bullying. Soul Journey. 